\title{
Clinical findings of the phakomatoses Tuberous sclerosis
}

\author{
Mark Quigg, MD, MSc; and James Q. Miller, MD
}

Tuberous sclerosis complex (TSC) remains a clinical diagnosis with its major and minor features outlined in consensus criteria. ${ }^{1}$ It is an autosomal dominant disease with high penetrance. About 15 to $20 \%$ of individuals have TSC that fails to be confirmed by current tests on genes TSC-1 (chromosome 9) and TSC-2 (chromosome 16). ${ }^{2}$ Phenotypic variability and early diagnosis combine to make the classic triad of mental retardation, seizures, and skin lesions infrequent. Figure 1 shows features of TSC that may be apparent on physical examination. Figure 2 shows some sequelae of CNS involvement.

\section{Editor's Note}

Sadly, Dr. James Q. Miller, senior author on the above article, died while this manuscript was under review. He will be greatly missed. Dr. Miller had a long legacy of teaching accomplishments and was widely loved by his trainees at all levels. His greatest teaching gifts included an ability to simplify material to the level of his learner and then build in the complex, resulting in a lasting understanding for the trainee. He encompassed the warmth, support, great clinical sense and communication skills from which students tend to learn best. He developed numerous durable teaching documents, including schematics, images and video tapes that will assure his continued contribution to education. We are pleased to continue to share his great love and skill for teaching with our readership.

\section{In Memoriam, page 1524}

\section{References}

1. Roach ES, Gomez MR, Northrup H. Tuberous sclerosis complex consesus conference: revised clinical diagnostic criteria. J Child Neurol 1998;13:624-628.

2. Roach ES, Sparagana SP. Diagnosis of tuberous sclerosis complex. J Child Neurol 2004; 19:643-649.
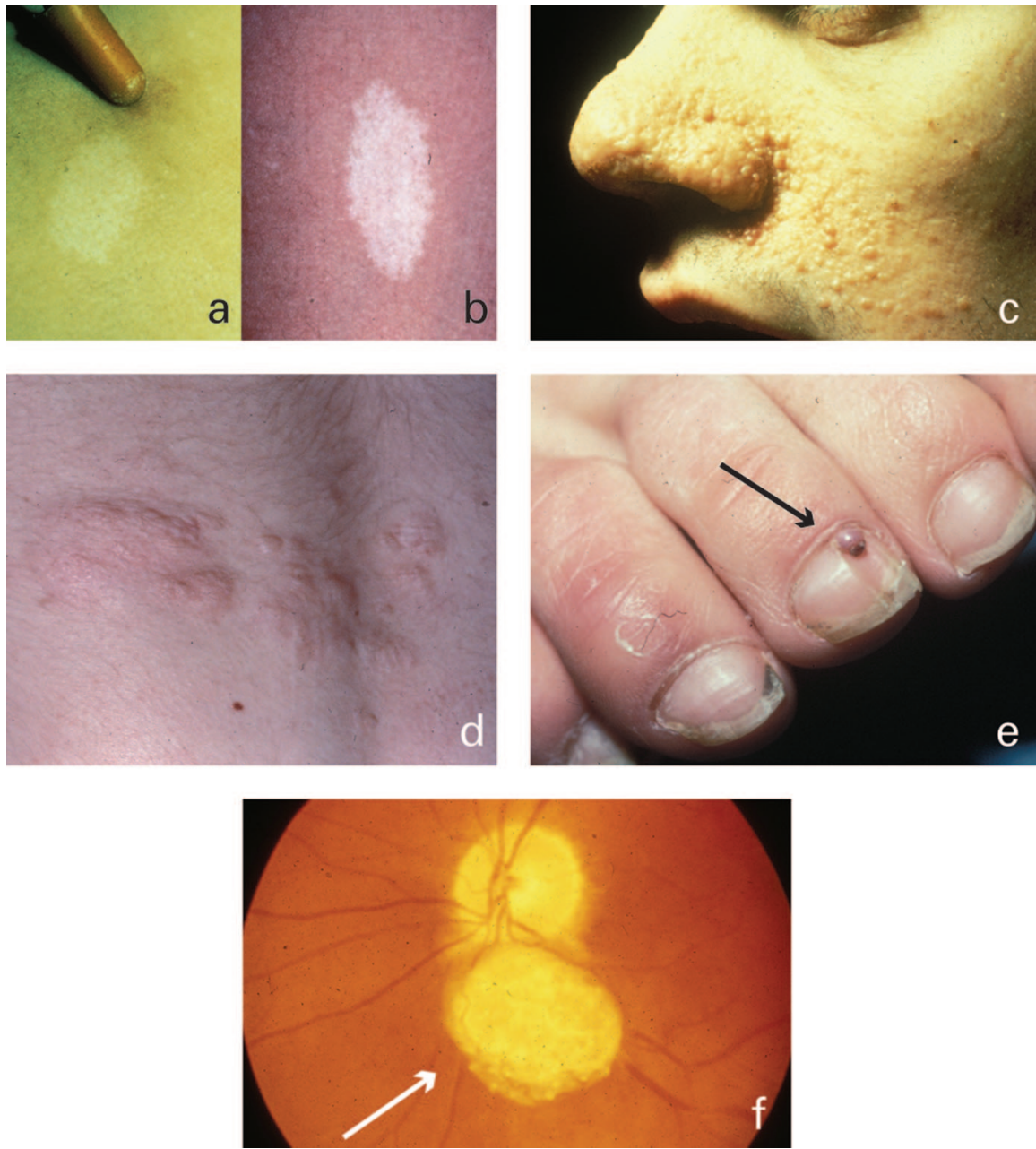

Figure 1. (A) Hypomelanotic macules, "ash leaf" spots, (B) accentuated with Wood's lamp (ultraviolet light) occur predominately on the thorax and legs and may be the first visible findings of tuberous sclerosis complex (TSC) in infants, as seen in this three year old boy. (C) Facial angiofibromas (adenoma sebaceum [AS]) appear on the nose, cheeks, and chin of this 5-year-old boy. AS appear within the first 5 years of life. (D) The lumbosacrum of a teenager has a midline Shagreen patch, confluent papules with a suede-like texture. (E) Subungual angiofibromas (arrow) are found in the nail beds of adults. (F) Retinal phakomas ("mulberry lesions," arrow) appear in the majority of adults; $87 \%$ of TSC cases will have retinal lesions, either phakomas or more subtle plaquelike hamartomas or depigmented areas. ${ }^{2}$ 

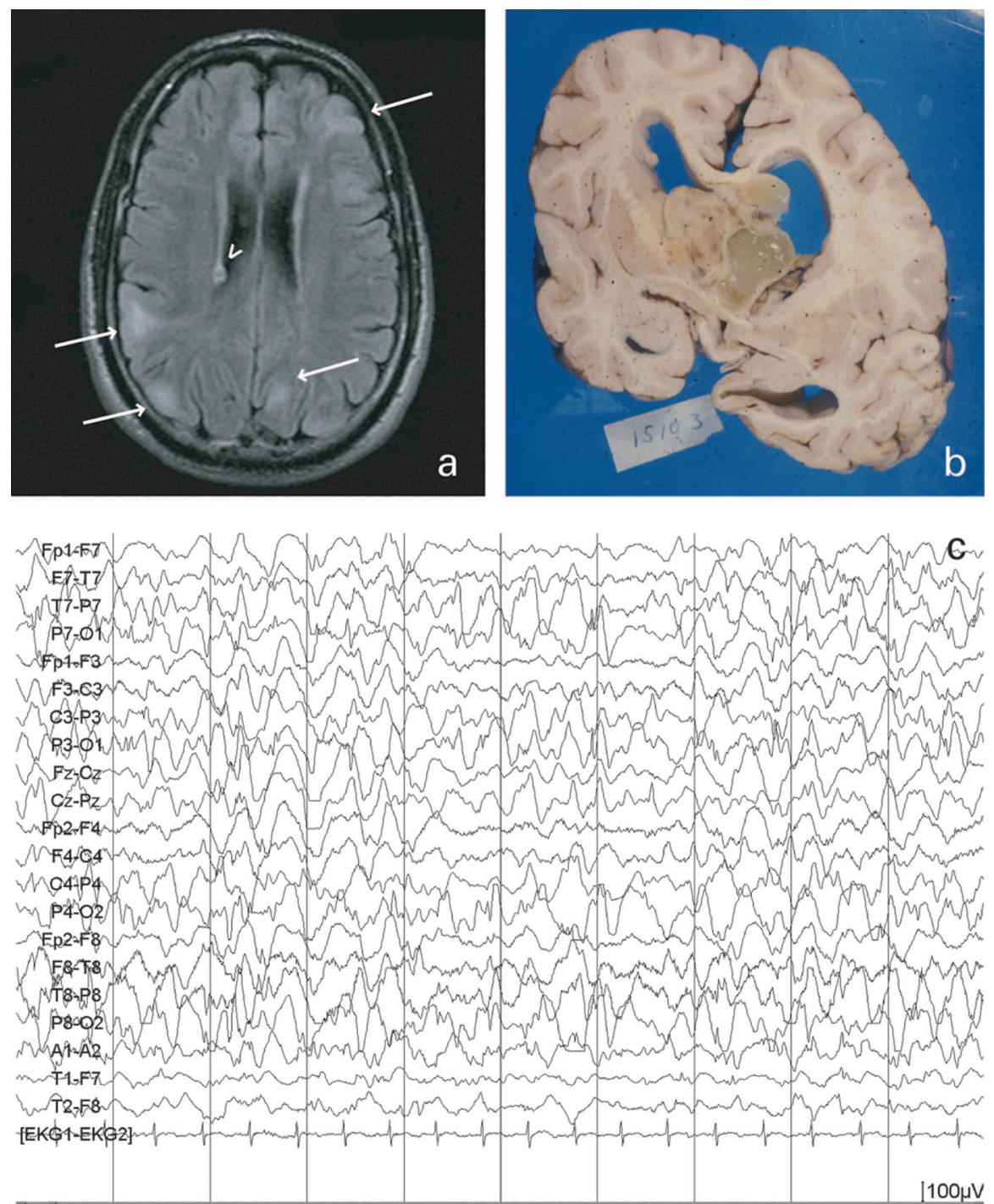

Figure 2. (A) Fluid-attenuated inversion recovery axial MRI reveals tubers (arrows) and subependymal hamartomas (arrowhead). (B) Autopsy specimen shows the cause of hydrocephalus in a case of giant cell astrocytomas evolved from subependymal hamartomas. (C) Arrhythmic, high amplitude, and disordered delta activity with multifocal independent spikes denoting hypsarrhythmia in an eight month old boy with infantile spasms and tuberous sclerosis complex. 


\section{Neurology}

\section{Clinical findings of the phakomatoses: Tuberous sclerosis Mark Quigg and James Q. Miller \\ Neurology 2005;65;E22-E23 \\ DOI 10.1212/01.wnl.0000185111.89432.95}

\section{This information is current as of November 21, 2005}

\section{Updated Information \&} Services

\section{Supplementary Material}

References

Permissions \& Licensing

\section{Reprints}

including high resolution figures, can be found at: http://n.neurology.org/content/65/10/E22.full

Supplementary material can be found at: http://n.neurology.org/content/suppl/2007/04/02/65.10.E22.DC1

This article cites 2 articles, 0 of which you can access for free at: http://n.neurology.org/content/65/10/E22.full\#ref-list-1

Information about reproducing this article in parts (figures,tables) or in its entirety can be found online at:

http://www.neurology.org/about/about_the_journal\#permissions

Information about ordering reprints can be found online:

http://n.neurology.org/subscribers/advertise

Neurology ${ }^{\circledR}$ is the official journal of the American Academy of Neurology. Published continuously since 1951, it is now a weekly with 48 issues per year. Copyright . All rights reserved. Print ISSN: 0028-3878. Online ISSN: 1526-632X.

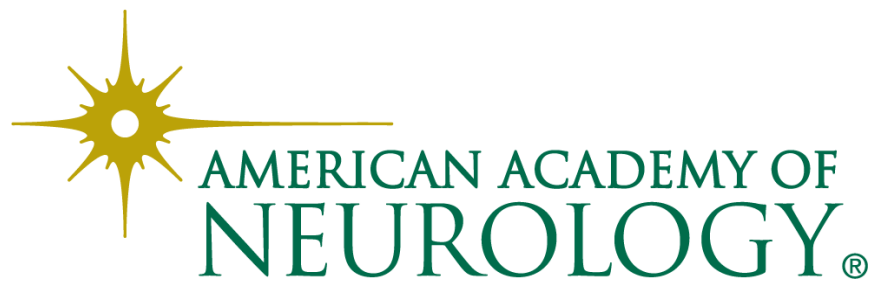

